DOI https://doi.org/10.30525/978-9934-588-80-8-1.47

\title{
КОНКУРЕНТНА ВІКТИМНІСТЬ ТА ЇЇ РОЛЬ У ДЕЗІНТЕГРАЦІЇ УКРАЇНСЬКОГО СУСПІЛЬСТВА
}

\author{
Гарькавець С. О. \\ доктор психологічних наук, професор, \\ професор кафедри психології та сочіології \\ Східноукраӥнський національний університет імені Володимира Даля
}

Волченко Л. П.

кандидат психологічних наук,

старший викладач кафедри педагогіки та психології

Луганський обласний інститут післядипломної педагогічної освіти

м. Сєвєродонещьк, Луганська область, Україна

Гостра конфліктна взаємодія ворогуючих сторін завжди супроводжується проявами віктимності та певними втратами, що стає показником їхньої спроможності знайти шляхи до примирення у майбутньому. При цьому роль жертви іноді обирається свідомо, коли один із суб'єктів конфлікту значно перебільшує власні страждання 3 метою отримання додаткових «бонусів», що пов'язані з його надією на підтримкою з боку інших, проявами їхнього милосердя, співчуття тощо. У даному випадку інсталюється так звана «конкурентну віктимність» («competitive victimhood» (CV)) [1], яка виникає з того, що суб'єкти конфлікту певною мірою усвідомлюють себе жертвами конфлікту (особливо в ситуації, коли власних ресурсів не вистачає для вирішення конфлікту на свою користь), а ті втрати, що вони несуть внаслідок його загострення, артикулюються як особливі, які не можливо порівняти з втратами опонентів.

Конкурентна віктимність описує зусилля суб'єктів конфлікту, які вони спрямовують на виправдання власних жорстких дій або поводження, оскільки вважають, що більше страждають у конфлікті, ніж протилежна сторона. Конкурентна віктимність стає однією 3 причин того, чому конфлікти (особливо військові) мають затяжний та руйнівний характер. А отже, конкурентна віктимність може бути й одним із пояснень щодо генерування соціального напруження та дезінтеграції соціальної структури українського суспільства за сучасних умов його розвитку.

Конкурентна віктимність - це перш за все актуалізація установки на віктимну активність, основним змістом якої $є$ артикуляція власного положення жертви, нав'язування оточуючим необхідності глибокого 
співчуття, милосердя та підтримки. Індивіди 3 конкурентною віктимністю вважають, що вони заслуговують на велику компенсацію своїх страждань, прагнуть закріпити, посилити, звеличити власне положення, яке надає відчуття зверхності як перед опонентами, так й перед тими, у кого вони прагнуть викликати відчуття провини за реалізовану власну віктимність [2; 3]. Конкурентна віктимність виступає феноменом, який відтворює установку конфліктуючих сторін на визнання саме їх жертвами протистояння, з метою отримання явних преференцій, всебічної підтримки, відновлення морального статусу, компенсації втрат та амністування за вчинення дій, що можуть бути визнані як злочинні.

У власних наукових студіях ми вже робили спробу розглянути прояви конкурентної віктимності у контексті соціального конфлікту, який відбувається на Південному сході України [4] та з'ясували, що конкурентна віктимність ворогуючих сторін значно зростає в умовах жорсткого протистояння за рахунок того, що збільшується кількість жертв не тільки фізичного, а й матеріального, культурного та психологічного змісту.

3'ясовано, що конкурентна віктимність має власні соціальнопсихологічні механізми, які зумовлюють різну амплітуду ії інсталяцію. M. Noor, N. Shnabel, S. Halabi, A. Nadler серед таких механізмів виокремлюють ідентифікацію, категоризацію та раціоналізацію [5; 6].

Механізм ідентифікації сприяє тому, що окремі індивіди іп-групи ототожнюються 3 іншими членами цієї групи, а групові переживання стають стимулом індивідуальної активності, у тому числі й віктимної. Механізм категоризації соціально стереотипізує явища віктимогенного змісту, а механізм раціоналізації забезпечує приховування справжніх мотивів віктимної поведінки індивідів і забезпечує їхній комфортний психічний стан, мінімізує відчуття провини та сорому за власні деструктивні дії, надає їм виправдувальних мотивів.

3'ясовано, що в українському суспільстві інсталюються й такі соціально-психологічні механізми конкурентної віктимності, як навіювання, наслідування, психічне зараження та конформізм [7]. Механізм навіювання забезпечує послаблення свідомого контролю та посилення некритичного сприйняття інформації, що призводить до зростання проявів конкурентної віктимності на рівні нав'язливого синдрому. Наслідування забезпечує посилення амплітуди прояву конкурентної віктимності, якщо конфліктуючі сторони невдоволені власним станом жертви й особливо тоді, коли вони відчують невдоволення тим, що їхні очікування були задоволені менше, ніж у супротивника. Це проявляється саме на рівні міжгрупового конфлікту, коли фізичні та психологічні страждання членів іn-групи призводять до розпаду нормативно-рольової поведінки та виникає «ефект юрби». 
Механізм конформізму артикулює пріоритет страждань іn-групи, які $є$ незрівнянно більшими, ніж страждання суб'єктів конфлікту з out-групи та «цементує» прояви конкурентної віктимності у міжгрупових конфліктах, оскільки є значущим чинником єдності та згуртованості членів групи.

3'ясовано, що значна частина українців має сегрегаційні установки, які тільки ускладнюють процес пошуку продуктивних алгоритмів щодо реінтеграції Донбасу. При цьому, як слушно зазначає I. Ф. Кононов: «... війна на Донбасі стала значним травматичним досвідом для регіональної спільноти... Більше того, є підстави вважати, що після війни цей досвід, перетворившись на колективні наративи, буде сприяти ще більшому увиразненню регіональної специфіки» [8]. Тобто, травматичний досвід у поєднанні з конкурентною віктимністю, через соціально-психологічні механізми може згенерувати навіть ідіосинкразію у відносинах між мешканцями Донбасу та іншими громадянами України.

Проте, ми можемо стверджувати, що підстави для об'єднання завжди $\epsilon$, тому що люди навіть в умовах розколотих спільнот зберігають загальне культурне коріння. Проблема завжди екстраполюється на рівні політичних еліт, що мають та переслідують власні егоїстичні інтереси. Але, як ми вже раніше зазначали, тягар, що пов'язаний з примиренням і прощенням значно легше, ніж постійні страждання у крузі нескінченного насилля [9].

\section{Література:}

1. Noor M., Brown R. J., Prentice G. Precursors and mediators of intergroup reconciliation in Northern Ireland: A new model // British Journal of Social Psychology. 2008. Vol. 47, № 3. P. 481-495.

2. Sullivan D., Landau M. J., Branscombe N. B., Rothschild Z. K. Competitive victimhood as a response to accusations of in-group harm doing // Journal of Personality and Social Psychology. 2012. Vol. 102. P. 778-795.

3. Young I. F., Sullivan D. Competitive victimhood: A review of the theoretical and empirical literature // Current Opinion in Psychology. 2016. Vol. 11. P. 30-34.

4. Гарькавец С. А. Проблема конкурентной виктимности и вооруженный конфликт на юго-востоке Украины // Вісник Одеського національного університету ім. І. І. Мечникова. Психологія. Т. 21, Вип. 2(42). 2016. С. 39-49.

5. Noor M., Shnabel N., Halabi S., Nadler A. When suffering begets suffering: The psychology of competitive victimhood between adversarial groups in violent conflicts // Personality and Social Psychology Review 2012. Vol. 16. P. 351-374. 
6. Shnabel N., Halabi S., Noor M. Overcoming competitive victimhood and facilitating forgiveness through re-categorization into a common victim or perpetrator identity // Journal of Experimental Social Psychology. 2013. Vol. 49. P. 867-877.

7. Гарькавець С. О. Конкурентна віктимність та ії психологічні механізми. // Теоретичні і прикладні проблеми психології : зб. наук. праць Східноукраїнського національного університету ім. В. Даля. Сєвєродонецьк: Вид-во СНУ ім. В. Даля, 2017. № 1 (42). С. 59-67.

8. Кононов І. Ф. Вплив війни на регіональну спільноту Донбасу // Тези доповідей та виступів учасників III Конгресу Соціологічної асоціації України «Нові нерівності - нові конфлікти: шляхи подолання» (12-13 жовтня 2017, м. Харків). Вид-во ХНУ ім. В. Н. Каразіна, 2017. C. $110-113$.

9. Гарькавец С. А., Яковенко С. И. Обида и ее инсталляция в контексте российско-украинских отношений // Электронный журнал / Фундаментальные исследования в практиках ведущих научных школ. 2014. № 4. URL:fund-issled-interm.esrae.ru/4-47 (дата звернення: 27.12.2017).

DOI https://doi.org/10.30525/978-9934-588-80-8-1.48

\title{
ПРОЯВИ ДЕВІАНТНОЇ АГРЕСІЇ У СПІЛКУВАННІ
}

\author{
Opoc O. Б. \\ кандидат соиіологічних наук, \\ дочент кафедри соиіології та соиіальної роботи \\ ДВНЗ «Ужгородський національний університет» \\ м. Ужгород, Украӥна \\ Спачинська C-E. I. \\ слухачка магістратури спеиіальності «Психологія» \\ Мукачівський державний університет \\ м. Мукачеве, Україна
}

Спілкування як процес встановлення та розвитку контактів між людьми, основний спосіб до розуміння іншої людини та засіб соціалізації, відіграє ключову роль у встановленні стосунків (дружніх, сімейних, ділових, партнерських). Проте сьогодні у часи суспільної кризи, пов'язаної в першу чергу із пандемією COVID-19, коли підвищений рівень стресу, посилення психопатологічної симптоматики, зниження можливості адекватно справлятися із стресом [1], спілкування все більше насичене деструктивними, девіантними проявами агресії, на 